Hydroécol. Appl. (1991) 1, pp. $111-124$

\title{
Petit-saut hydroelectric scheme : vegetal associations of stagnant waters in French Guyana
}

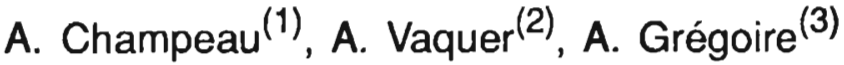

(1) Laboratoire d'Hydrobiologie, Université de Provence, Centre St Charles, Place V. Hugo, F13331 MARSEILLE Cedex 3.

(2) Laboratoire d'Hydrobiologie Marine et Continentale, Université de Montpellier II, Case 093, Place E. Bataillon, F-34095 MONTPELLIER Cedex 5.

(3) E.D.F., Direction Equipement, Service I.D.E., 22-30 Avenue de Wagram, F-75382 PARIS Cedex 08.

Summary. - Hydroelectric plant of Petit Saut is under construction on the river Sinnamary in French Guyana. The future reservoir will flood a $300 \mathrm{~km}$ area of virgin forest. Under tropical climate as in Brazil or Surinam, the reservoirs are often overgrown with macrophyte vegetation during several years from the start of flooding operations. In order to assess the risks of vegetal proliferations in the future reservoir of Petit Saut, macrophyte lists have been made out with special attention to some prolific species (Eichhornia crassipes, Salvinia auriculata, Pistia stratiotes, Oxycarium cubense, etc.) in all types of aquatic environments (marshes, ditches, canals, ricefields, etc) by using phytosociological method (abundance/dominance indice).

A correspondence analysis of data have permitted to show the relationships between specific vegetal communities and typical water environments. The spatial distribution of the macrophyte communities in these various environments according to their limnological features constitute a starting point for devising the mean to limit their proliferations.

Key Words : man-made lake; macrophytes; equatorial region; French Guyana; management; restoration.

Résumé. - Le barrage hydroélectrique de Petit-Saut est en construction sur la rivière Sinnamary en Guyane française. La future retenue inondera une surface de $300 \mathrm{~km}$ de forêt vierge. En région tropicale comme au Brésil ou au Surinam, les réservoirs sont souvent envahis par une végétation macrophytique pendant plusieurs années suivant la mise en eau.

Afin d'évaluer les risques de prolifération des végétaux dans la future retenue de $\mathrm{Pe}$ tit-Saut, un inventaire des macrophytes a été dressé en portant une attention particulière aux quelques espèces (Eichhornia crassipes, Salvinia auriculata, Pistia stratiotes, Oxycarium cubense, etc.) qui prolifèrent dans tous les types de milieux aquatiques (marais, fossés, canaux, rizières, etc.). La méthode phytosociologique basée sur la prise en compte de l'indice d'abondance/dominance a été utilisée.

Une analyse des correspondances a permis de montrer la relations entre les communautés d'espèces végétales et les milieux aquatiques types. La connaissance de la distribution spatiale des communautés macrophytiques expliquée par les conditions de milieu constitue un point de départ à la recherche des moyens de lutte contre leur prolifération. 


\section{1. - INTRODUCTION}

The hydroelectric power station of Petit Saut is under construction on the river Sinnamary in French Guyana. The site of the future reservoir is covered by the permanent amazonian primary forest. The vegetal biomass which will be flooded is assessed at about 12 millions tons carbon equivalent.

Although the water intake will be situated close to the bottom of the lake, it will drain off water from epilimnion because of a 'pre-dam' whose the top will be leveled at $15 \mathrm{~m}$ below the top of the main dam.

In comparison with numerous tropical reservoirs, the renewal time of the water will be relatively short (five months) and therefore favourable to aquatic life.

For economic reasons, the flooded area will not be deforested. Consequently, a proliferation of aquatic macrophytes is foreseeable during the first years as it is frequently observed in these latitudes. It follows at once impacts of physico-chemical and biological nature.

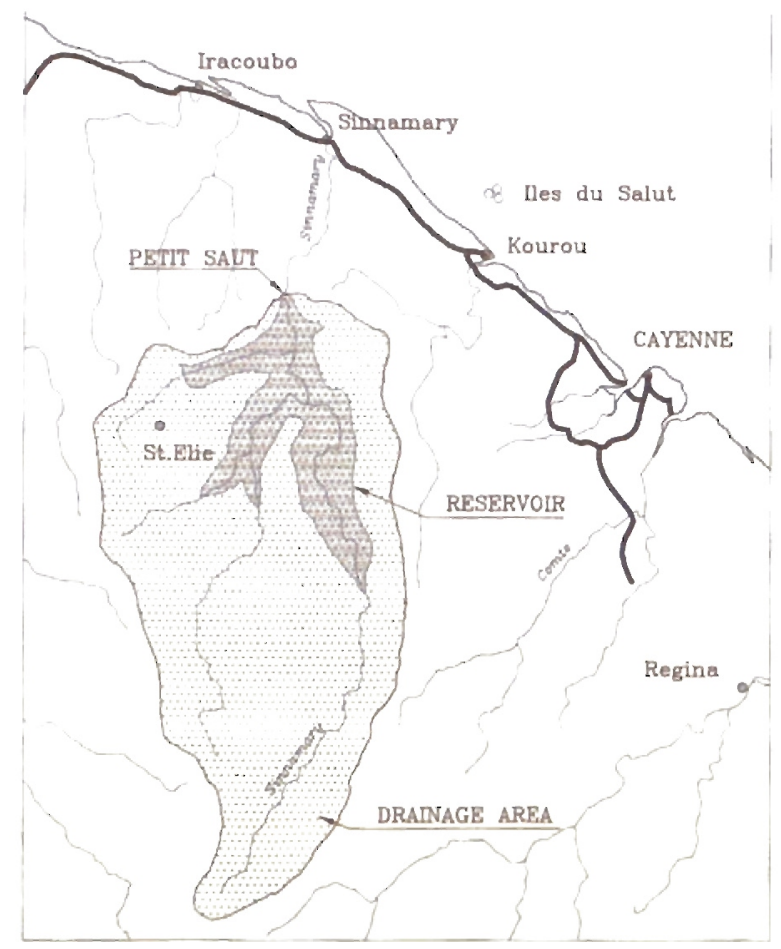

Fig. 1. - Location of the future reservoir of Petit-Saut and its drainage basin in French Guyana. 
Table 1. - Physical and chemical characteristics of the River Sinnamary in French Guyana.

\begin{tabular}{|l|c|c|c|}
\hline Temperature & $23-28$ & $\mathrm{Fe}^{+++}(\mathrm{mg} /)$ & 0,25 \\
\hline $\mathrm{pH}$ & $5,4-6,5$ & $\mathrm{Ca}^{++}(\mathrm{mg} /)$ & 0,25 \\
\hline Conductivity & $11-35$ & $\mathrm{Mg}^{++}(\mathrm{mg} /)$ & 0,41 \\
\hline $\mathrm{O}_{2}$ (mg/) & $7,4-8,6$ & $\mathrm{~K}^{+}(\mathrm{mg} / 1)$ & 0,52 \\
\hline Transparency & $0,8-1,6$ & $\mathrm{Na}^{+}(\mathrm{mg} / \mathrm{l})$ & 2,53 \\
\hline $\mathrm{NO}_{3}^{-}$ & $0,33-1$ & $\mathrm{Cl}^{-}(\mathrm{mg} / \mathrm{l})$ & 2,90 \\
\hline $\mathrm{PO}_{4}^{-}$(mg/l) & $0,04-0,09$ & & \\
\hline S.s.s. & (mg/) & $7-35$ & \multicolumn{2}{|c|}{ 'S.s.s. Settleable suspended solids } \\
\hline
\end{tabular}

The aim of this study is to evaluate the importance of the risks resulting from the growth of these macrophytes in French Guyana, in order to plan as soon as possible the most suitable means of weeds control.

\section{THE RIVER SINNAMARY}

The reservoir of Petit-Saut will flood a $300 \mathrm{~km}^{2}$ area and will extend over $80 \mathrm{~km}$ of the course of the river Sinnamary (Figure 1).

The river Sinnamary may be grouped together with the clear water rivers according to the current classification of the Amazonian rivers (Sioli, 1975; Paiva, 1977). The water is strongly acid and very weakly mineralized. The most suspended particles consist of very small vegetal fragments.

The humic acids decrease the water transparency and colour the water brown-yellow. The slight quantities of nutrients are typical of oligotrophic aquatic environments (Table 1).

\section{MATERIAL AND METHODS}

The study was carried out in 1987. A total of 294 sites examined are distributed among nine geographical regions (Fig. 2A) and according to six types of environment (Fig. 2B). These regions are localized in all the coastal plain of French Guyana because aquatic environments are lacking in the area of the future reservoir and its drainage basin except creeks and some borrow pits and ditches which are colonized by a very specific vegetation under the forest cover. $\mathrm{pH}$ (pHmeter), conductivity (conductimeter), color (platino-cobalt APHA colorimetric method), turbidity (nephelometric method), Fe (phenanthroline colorimetric method), $\mathrm{Ca}$ 


\section{Nb. stations}

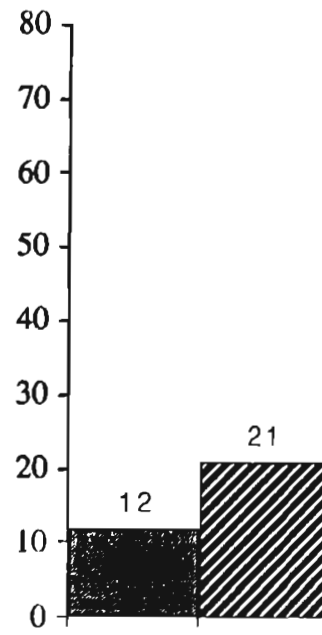

Regina Kaw Cayenne Tonate Kourou Sinnamary Mana Iracoubo St Laurent

Nb. stations

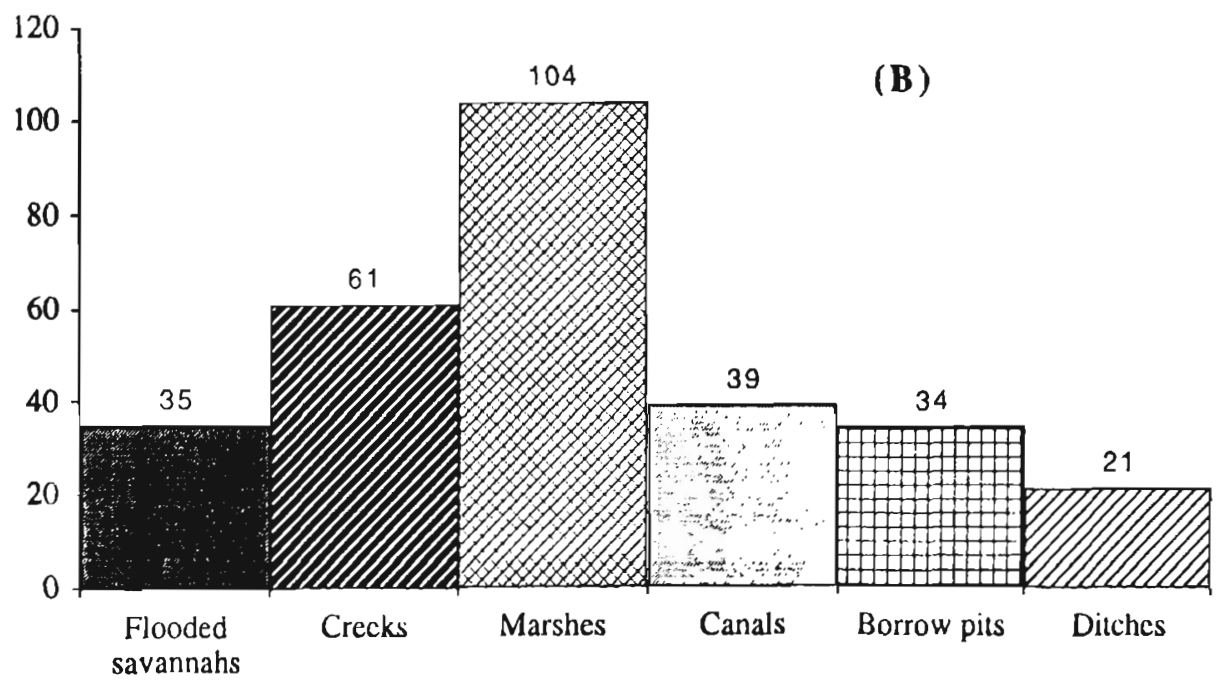

Fig. 2. - Frequencies of stations according to geographical area (A) and the different aquatic environments (B). 
(EDTA complexometry method), mineral nitrogen as sum of ammonium-N (Nessler method), nitrate$\mathrm{N}$ (naphthtylamine colorimetric method) and nitrite- $\mathrm{N}$ (diazotation and naphthtylamine colorimetric method) were measured as much as possible.

The vegetation was studied according to classical phytosociological methods. In each site, a floristic list was drawn up. Plants were identified according to Lemee (1952-1956), Cook (1974), Fournet (1978), Gopal (1987). An abundance index (1-6) expressed as cover abundance $(<1 \%$; $1-10 \% ; 10-25 \%$; $25-50 \%$; $50-75 \%$ and $75-100 \%$ of the vegetated area) and a sociability index (1-6) indicating the distribution pattern of plants in the site (1-isolated individuals to 6-totally clustered) were associated to each observed species.

The original phytosociological data set (294 observations $\times 104$ species) was reduced to 275 observations $x$ 76 species by removing species observed in less than $1 \%$ of the sites and sites under forest and analyzed using Correspondence Analysis. Computations were performed using BIOMECO Program (v.2.0, 1987, Groupe BIOMETRIE du CEPE-CNRS; F-Montpellier).

Table 2. - Physical and chemical characteristics of waters in the different aquatic environments in the littoral area of French Guyana. $(N=$ number of measures; S.d. = Standard Deviation).

\begin{tabular}{|c|c|c|c|c|c|c|c|c|}
\hline & & $\begin{array}{l}\text { Color } \\
\text { Hazen } \\
\text { units }\end{array}$ & $\begin{array}{l}\text { Turbidity } \\
\text { JTU }\end{array}$ & pH & $\begin{array}{l}\text { Conductivity } \\
\mu \mathrm{S} \mathrm{cm}^{-1}\end{array}$ & $\begin{array}{c}\mathrm{Fe} \\
\mathrm{mg} \mathrm{I}^{-1}\end{array}$ & $\begin{array}{c}\mathrm{Ca} \\
\mathrm{mg} \mathrm{I}^{-1}\end{array}$ & $\underset{\mathrm{N}}{\operatorname{mineral}} \mathrm{mg} \mathrm{l}^{-1}$ \\
\hline Marshes & $\begin{array}{l}\text { Mean } \\
\text { Range } \\
\mathrm{N} ; \mathrm{Sd}\end{array}$ & \begin{tabular}{|l|}
218.9 \\
$25-1350$ \\
$32 ; 269.9$
\end{tabular} & $\begin{array}{l}32.5 \\
0-122 \\
24 ; 39.7\end{array}$ & $\begin{array}{l}5.5 \\
4.9-7.1 \\
21 ; 05\end{array}$ & $\begin{array}{l}274.8 \\
18-2500 \\
37 ; 485.7\end{array}$ & $\begin{array}{l}0.3 \\
0.1-1.5 \\
27 ; 0.3\end{array}$ & $\begin{array}{l}7.0 \\
0.1-54 \\
19 ; 20.6\end{array}$ & $\begin{array}{l}1.9 \\
0.2-4.5 \\
25 ; 1.3\end{array}$ \\
\hline Savannahs & $\begin{array}{l}\text { Mean } \\
\text { Range } \\
\mathrm{N} ; \mathrm{Sd}\end{array}$ & $\begin{array}{l}105.7 \\
20-270 \\
15 ; 74.1\end{array}$ & $\begin{array}{l}13.5 \\
0-55 \\
10 ; 18.9\end{array}$ & $\begin{array}{l}5.3 \\
4.6-5.9 \\
12 ; 0.4\end{array}$ & $\begin{array}{l}27.9 \\
15-85 \\
15 ; 17.5\end{array}$ & $\begin{array}{l}0.2 \\
0.1-0.7 \\
13 ; 0.2\end{array}$ & $\begin{array}{l}0.2 \\
0.1-0.4 \\
3 ; 0.3\end{array}$ & $\begin{array}{l}1.4 \\
0.9-2.6 \\
9 ; 0.5\end{array}$ \\
\hline Creeks & $\begin{array}{l}\text { Mean } \\
\text { Range } \\
\mathrm{N} \text {; Sd }\end{array}$ & $\left|\begin{array}{|l|}168.6 \\
10-1700 \\
42 ; 262.9\end{array}\right|$ & $\begin{array}{l}17.3 \\
0-280 \\
37 ; 46.3\end{array}$ & $\begin{array}{l}5.6 \\
4-7 \\
35 ; 0.6\end{array}$ & $\begin{array}{l}116.4 \\
18-1280 \\
43 ; 214.3\end{array}$ & \begin{tabular}{|l|}
0.3 \\
$0.05-1.6$ \\
$35 ; 0.3$
\end{tabular} & $\begin{array}{l}1.9 \\
0-11.2 \\
25 ; 3.9\end{array}$ & $\begin{array}{l}1.7 \\
0.5-3.4 \\
34 ; 0.9\end{array}$ \\
\hline Canals & \begin{tabular}{l|} 
Mean \\
Range \\
N; Sd
\end{tabular} & \begin{tabular}{|l|}
396.8 \\
$0-1125$ \\
$13 ; 358.3$
\end{tabular} & \begin{tabular}{|l|}
55.6 \\
$5-180$ \\
$11 ; 55.3$
\end{tabular} & $\begin{array}{l}5.9 \\
4-7.4 \\
12 ; 1\end{array}$ & \begin{tabular}{|l|}
675.5 \\
$77-2700$ \\
$14 ; 796.9$
\end{tabular} & $\begin{array}{l}0.4 \\
0.05-1.6 \\
11 ; 0.4\end{array}$ & $\begin{array}{l}6.1 \\
0.2-20 \\
11 ; 9.6\end{array}$ & $\begin{array}{l}2.1 \\
0.8-3.8 \\
8 ; 1.1\end{array}$ \\
\hline Ditches & $\begin{array}{l}\text { Mean } \\
\text { Range } \\
\mathrm{N} ; \mathrm{Sd}\end{array}$ & \begin{tabular}{|l|}
336.2 \\
$5.3-1200$ \\
$13 ; 325.0$
\end{tabular} & $\begin{array}{l}93.2 \\
15-680 \\
12 ; 186.9\end{array}$ & $\begin{array}{l}6.1 \\
5.2-7.5 \\
8 ; 0.7\end{array}$ & \begin{tabular}{|l|}
459.5 \\
$17-2010$ \\
$13 ; 587.6$
\end{tabular} & $\begin{array}{l}0.5 \\
0-1.8 \\
11 ; 0.5\end{array}$ & \begin{tabular}{|l|}
11.1 \\
$0.1-52$ \\
$11 ; 27.8$
\end{tabular} & \begin{tabular}{|l|}
1.9 \\
$0.55-4.1$ \\
$8 ; 1.1$
\end{tabular} \\
\hline Borrow pits & $\begin{array}{l}\text { Mean } \\
\text { Range } \\
\mathrm{N} ; \mathrm{Sd}\end{array}$ & $\begin{array}{l}105.6 \\
20-310 \\
18 ; 73.1\end{array}$ & $\begin{array}{l}11.3 \\
0-38 \\
12 ; 10.8\end{array}$ & $\begin{array}{l}5.9 \\
5.4-6.5 \\
13 ; 0.3\end{array}$ & $\begin{array}{l}31.3 \\
12-84 \\
20 ; 21.1\end{array}$ & $\begin{array}{l}0.1 \\
0.1-0.5 \\
15 ; 0.1\end{array}$ & $\begin{array}{l}1.1 \\
0.2-4 \\
14 ; 1.8\end{array}$ & $\begin{array}{l}1.6 \\
0.6-2.6 \\
14 ; 0.7\end{array}$ \\
\hline
\end{tabular}




\section{RESULTS}

The main physico-chemical features of water sites summarized in Table 2 indicate that borrow pits and flooded savannahs are in general very soft environments. In contrast canals and ditches are much more mineralized. The slight values correspond to some ditches of the interior. Marshes and creeks are characterized by large ranges of variation of the measured parameters. Some sites are influenced by saline coastal waters.

The floristic list is composed of 104 taxonomic units (Annex 1), belonging to 36 families and 61 genera. The families Cyperaceae and Gramineae group respectively $24 \%$ and $20 \%$ of the species. $65 \%$ of the species are helophytes (with emergent leaves and/or stems) and $24 \%$ are hydrophytes (typical aquatic plants, free-floating, rooted, entirely submersed). $59 \%$ of the species have been observed at the most in 10 stations. Seven plant species were present in over 40 stations and three grew in a station out of 3 (Fig. 3). The specific richness is very variable between stations, from 1 to 21 species by station. The two thirds of the prospected aquatic en. vironments were colonized by 2 to 8 macrophytes (Fig. 4). The analysis of data being collected in all sites indicate 30 to 40 plant species relatively abundant. All the macrophytes being considered as nuisance have been observed, but their distribution are very inequal. For example, Echinochloa, Oxycarium and Salvinia are present uniformly in all the littoral area. The distribution of these species results from their

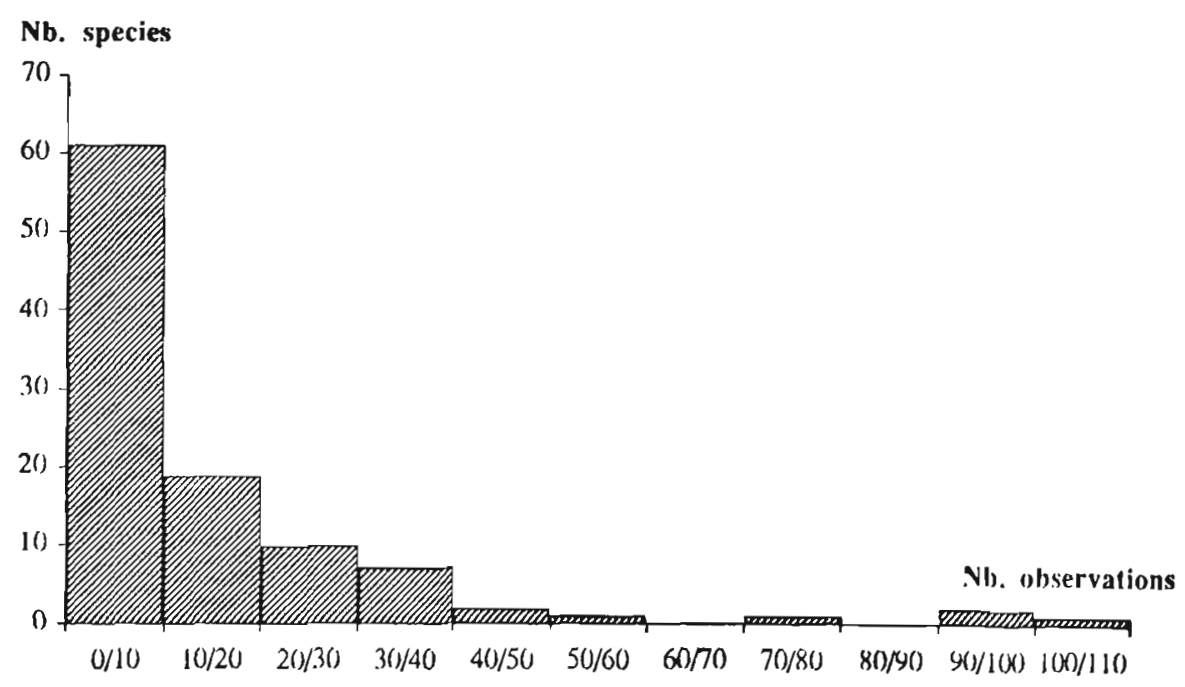

Fig. 3. - Frequencies of the plant species according to the number of their observations. 


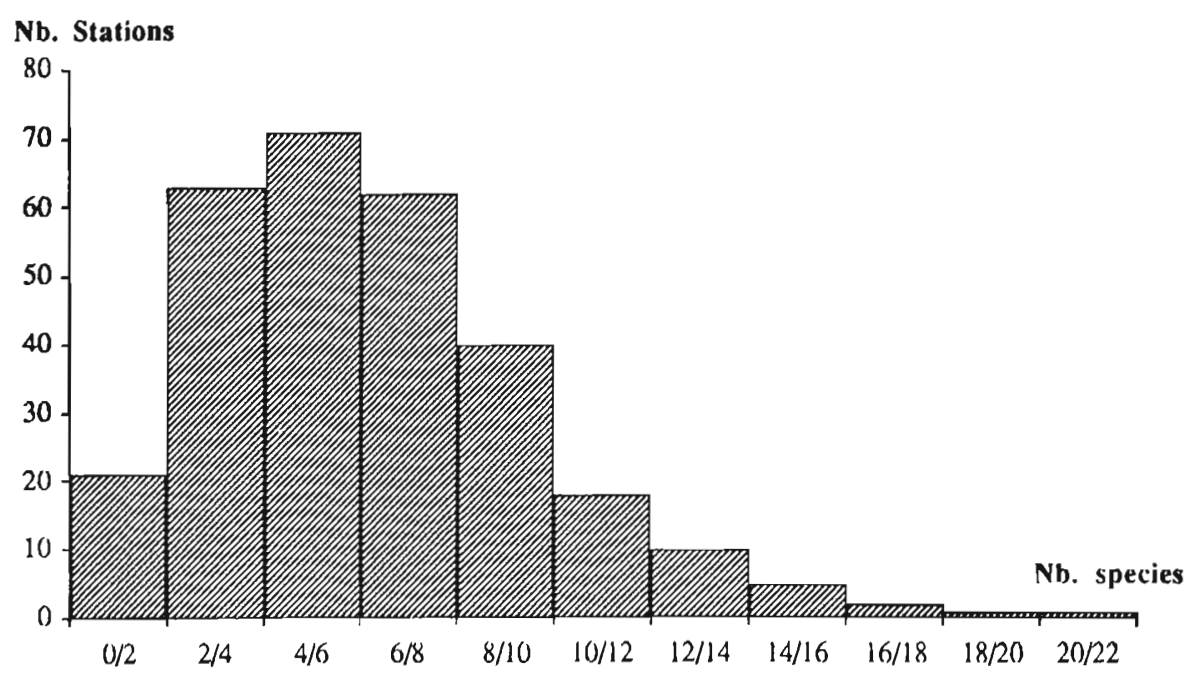

Fig. 4. - Frequencies of the observation stations according to the number of plant species.

tolerance as regards to main environmental parameters. The development of Salvinia should be contained by low conductivity levels (<60 $\mu \mathrm{S} \mathrm{cm-1;} \mathrm{Junk,} \mathrm{1982).} \mathrm{In} \mathrm{con-}$ trast, Pistia and Eichhornia are present in limited areas. Data about sites being colonized by Pistia are too scarce and do not permit to discuss its distribution. In the other hand, several factors can explain the development of Eichhornia in a few stations. This development could be controled by low values of $\mathrm{pH}$ (<5; Berg, 1961), low concentrations of nitrogen (Chadwick \& Obeid, 1966) and above all by 100 low concentrations of calcium (OKi et al., 1978; Desougi, 1984) as being measured in numerous sites, particularly in borrow pits, flooded savannahs and creeks.
All these species are present in the regions bordering French Guyana. The distribution of Eichhornia in the regions of Kaw and Mana corresponds to relatively high abondances in the bordering regions of Brazil and Surinam (Gopal, 1987). Oxycarium, abundant in Brazil and frequent in French Guyana, is more scarce in Surinam (Jonker Verhoef, 1968).

The results from the correspondence analysis of data clearly indicate the discrimination between types of aquatic environments and their floristic communities. The positioning of the sites and the species on the first ordination diagram (axis 1*2) indicating an important Guttman effect, the axis 3 has been examinated. The positioning of the sites on the ordination diagram 


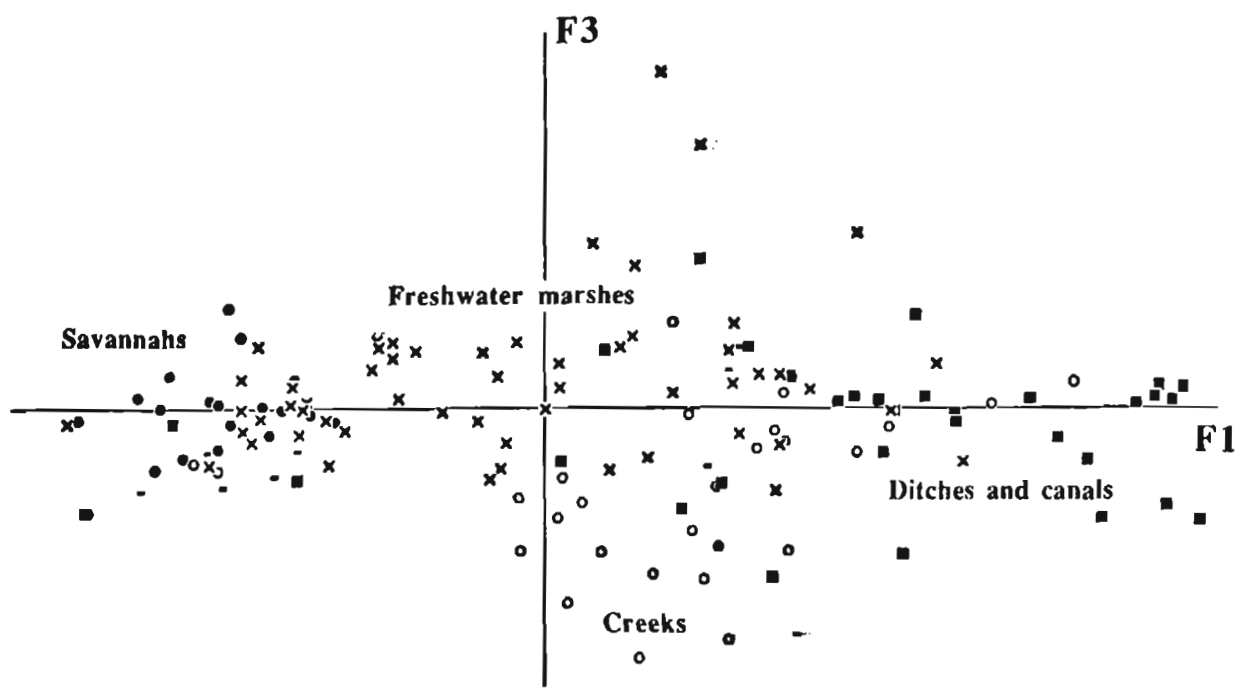

Fig. 5. - Correspondence analysis. Positioning of the different aquatic environments in ordination diagram, axis $1 \% 3$.

1 Cyperus arliculatus

1) Fuirenu umbellata

19 Rhynchospora huloschuenoides

I) Rhynchospora corymbosa

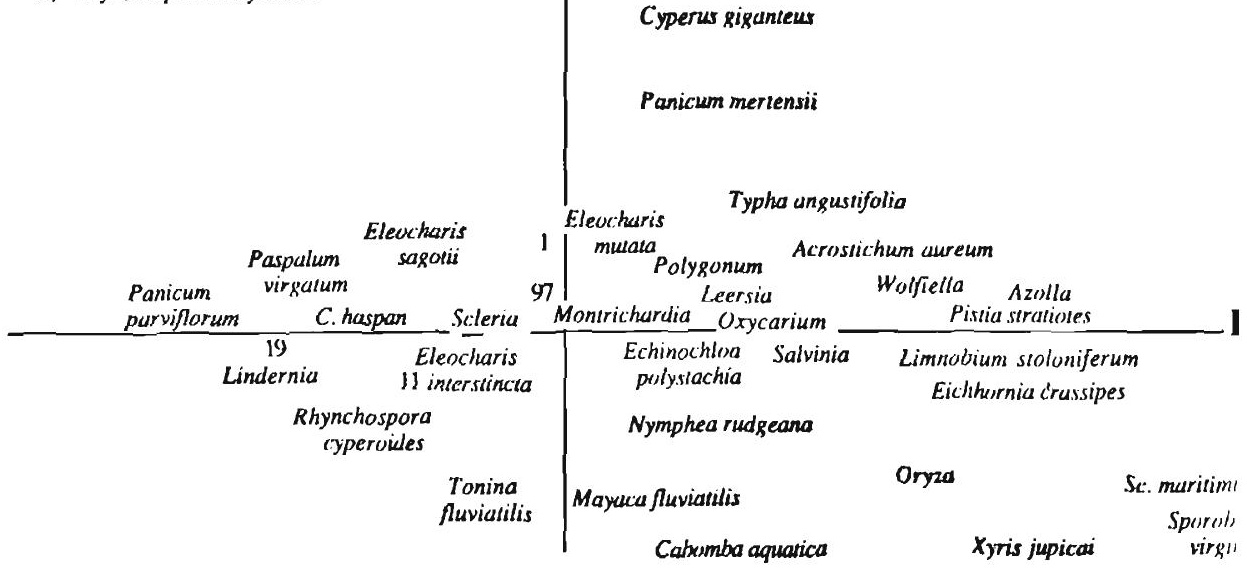

Fig. 6. - Correspondence analysis. Positioning of the species in ordination diagram, axis 1*3. 
(axis 1*3; Fig. 5) indicates a gradient on the axis 1 from flooded savannahs to ditches and canals. This gradient could represent the evolution from temporary, natural and soft, aquatic environments to permanent, often artificial and more mineralized, aquatic environments. Freshwater marshes are in intermediate position. The axis 3 could discriminate permanent and temporary stagnant waters in opposition of slowly running waters (creeks).

Creeks and borrow pits under forest cover are not considered in this analysis. They form a particular group of sites, with poor lists of macrophytes dominated by Thurnia. The discrimination of these different aquatic environments corresponds with distinguishing groupments of plants (ordination diagram, Fig. 6). The axis 1 separates the helophytes in negative position from hydrophytes which form floating mats (Leersia, Oxycarium, Echinochloa, Polygonum, etc.) in marshes and artificial environments and from floating hydrophytes (Wolfiella, Azolla, Pistia, Eichhornia, etc.), often in environments under human influence.

The examination of floristic lists in the different types of environment and the ordination of the sites and species allow to distinguish different communities being caracterized by dominant species and associated plants (Table 3).

Marshes (facies 1) caracterized by Typha angustifolia and Cyperus articulatus are quite similar to marshes being described in Surinam by Lindeman (1953), although these spe- cies were never observed as co-dominant in this study.

Marshes (facies 2) being caracterized by Eleocharis interstincta and Rhynchospora corymbosa are very frequent in French Guyana. They were also observed by Lindeman in Surinam and Guyana. In strongly mineralized marshes deep water zones are colonized by Nymphea ampla, Azolla and Lemna minor as it was observed by de Granville (1976).

\section{Weed control}

Owing to the distribution of the aquatic macrophytes in French Guyana and their preferences for the main limnological features, Oxycarium, Echinochloa, Salvinia and Eichhornia in a lesser extent seem to be the main probable proliferating macrophytes in the future man-made lake. Because of the risks of invasion of the future lake by weeds and their economical and ecological implications, it is very important to think about the means to control their development.

Chemical control have been attempted particularly against water hyacinth. 2,4-D was the most used herbicide, but showed important side effects because of its brutal and rapid action (Leidermann \& Figueiredo, 1967; Philipp et al., 1983). Some more progressive herbicides as glyphonate are less detrimental for environment (Pieterse \& Rijn, 1974). Nevertheless herbicide mixtures are in general better than a product alone because of their large sphere of ac- 
Table 3. - Dominant species and associated plants observed in the different water environments of the littoral area of French Guyana.

\begin{tabular}{|c|c|c|c|}
\hline Environments & Dominant species & Associated species & Assoclated species \\
\hline Brackish marshes & $\begin{array}{l}\text { Scirpus maritimus - Eleocharis mutata } \\
\text { Paspalum vaginatum - Sporobolus virginicus }\end{array}$ & $\begin{array}{l}\text { Acrostichum aureum - Torulinum ferax } \\
\text { Ludwigia leptocarpa - Typha angustifolia }\end{array}$ & $\begin{array}{l}\text { Nymphea ampla } \\
\text { Azolla caroliniana } \\
\text { Lemna minor }\end{array}$ \\
\hline $\begin{array}{l}\text { Freshwater marshes } \\
\text { (Facies 1) }\end{array}$ & $\begin{array}{l}\text { Typha angustifolia - Eleocharis sagotii } \\
\text { Cyperus articulatus }\end{array}$ & $\begin{array}{l}\text { Fuirena umbellata - Cyperus haspan } \\
\text { Cyperus polystachios - Leersia hexandra } \\
\text { Paspalum virgatum - Panicum parviflorum } \\
\text { Rhynchospora corymbosa }\end{array}$ & $\begin{array}{l}\text { Nymphea amazonum } \\
\text { Utricularia sp. } \\
\text { Salvinia auriculata }\end{array}$ \\
\hline $\begin{array}{l}\text { Freshwater marshes } \\
\text { (Facies 2) }\end{array}$ & $\begin{array}{l}\text { Eleocharis interstincta } \\
\text { Rhynchospora corymbosa }\end{array}$ & $\begin{array}{l}\text { Fuirena umbellata - Cyperus haspan } \\
\text { Rhynchospora corymbosa - Leersia hexandra } \\
\text { Scleria microcarpa - Ah. holoschoenoides } \\
\text { Montrichardia arborescens - Lindernia }\end{array}$ & $\begin{array}{l}\text { Mayaca longipes } \\
\text { Myriophyllum spicatum }\end{array}$ \\
\hline $\begin{array}{l}\text { Freshwater marshes } \\
\text { (Facies 3) }\end{array}$ & $\begin{array}{l}\text { Montrichardia arborescens } \\
\text { Blechnum serrulatum }\end{array}$ & $\begin{array}{l}\text { Panicum mertensii - Cyperus giganteus } \\
\text { Polygonum acuminatum } \\
\text { Limnobium stoloniferum }\end{array}$ & $\begin{array}{l}\text { Utricularia sp - Wolfiella sp } \\
\text { Salvinia auriculata - } \\
\text { Pistia stratiotes }\end{array}$ \\
\hline Flooded savannahs & $\begin{array}{l}\text { Paspalum virgatum - Panicum parviflorum } \\
\text { Rhynchospora cyperoides - Lindernia } \\
\text { Cyperus haspan - Rh. holoschoenoides }\end{array}$ & $\begin{array}{l}\text { Heliconia psittacorum - } \\
\text { Eleocharis interstincta } \\
\text { Fuirena umbellata - Nymphoides indica }\end{array}$ & $\begin{array}{l}\text { Mayaca - Myriophyllum - } \\
\text { Utricularia }\end{array}$ \\
\hline Creeks & $\begin{array}{l}\text { Montrichardia arborescens } \\
\text { Limnobium stoloniferum }\end{array}$ & & $\begin{array}{l}\text { Cabomba aquatica - } \\
\text { Pistia stratiotes } \\
\text { Salvinia auriculata - } \\
\text { Wolfiella - Utricularia }\end{array}$ \\
\hline $\begin{array}{l}\text { Water environment in } \\
\text { forest (in general } \\
\text { creeks or borrow pits) }\end{array}$ & $\begin{array}{l}\text { Thurnia } \\
\text { Tonina fluviatilis }\end{array}$ & & \\
\hline $\begin{array}{l}\text { Canals (artificial water } \\
\text { environments, as } \\
\text { ricefields...) }\end{array}$ & $\begin{array}{l}\text { Eichhornia crassipes - Eichhornia azurea } \\
\text { Echinochloa polystachia - Oxycarium cu- } \\
\text { bense } \\
\text { Nymphea rudgeana }\end{array}$ & $\begin{array}{l}\text { Polygonum acuminatum } \\
\text { Leersia hexandre - Polygonum acuminatum } \\
\text { Limnobium stoloniferum }\end{array}$ & $\begin{array}{l}\text { Salvinia auriculata - } \\
\text { Wolfiella } \\
\text { Pistia stratiotes - Azolla } \\
\text { Utricularia }\end{array}$ \\
\hline Borrow pits & $\begin{array}{l}\text { Rhynchospora cyperoides - Fuirena umbellata } \\
\text { Eleocharis interstincta - Nymphea }\end{array}$ & & $\begin{array}{l}\text { Salvinia - Tonina - } \\
\text { Cabomba - Wolfiella }\end{array}$ \\
\hline
\end{tabular}


tivity. They could allow to diminish the quantities of each herbicide (Widyanto et al., 1979).

Varied methods of biological control have also been attempted essentially against water hyacinth (Bennett, 1984; Wright \& Center, 1984). Herbivorous fishes (Lasher, 1967, Sutton, 1977), turtles (Carr, 1952; Tonopi \& Varghese, 1983), insects Coleoptera and Orthoptera (Bennett \& Zwölfer, 1968; Forna \& Bourne, 1984) and lamantins (Anonyme, 1983) have been introduced in diverse environments. But the results were limited because of the difficulties of individual adaptation of the animal species. Some fungus as Alternaria, Uredo, etc. have shown interesting morphological and physiological effects on hyacinth growth (Addor, 1977; Conway et al., 1979; Theriot, 1981). Therefore these effects are not strong enough owing to the growth capacity of the weeds.

Mechanical digger, cutting are also used, notably in guyanese ricefields. But the use of these mechanical methods is unrealistic in reservoirs because of the very large extent of weed mats. In contrast floating mats being more often anchored on the branches of submersed trees could be destructed by controled fluctuations of water levels. This method seems to be an efficient mean of weed control (Junk, 1982).

Considering the morphometric and hydraulic characteristics of the future reservoir, i.e. strongly jagged shoreline, relatively short renewall time and submersed forest, quite similar to those of the reservoir of Tucurui on the river Tocantins in Brazil (M.F. de Oliverra Filho, Centro de Protecao Ambiential, U.H.E. Tucurui, oral comm.) where only about $10 \%$ of the surface is covered by floating mats, this method could be preferred owing to the best environmental conservation.

\section{CONCLUSION}

The study of the aquatic vegetation in 294 sites including all the types of environments relatively close to the future reservoir indicates the high probability of its colonization by several macrophytes. The correspondence analysis of floristic data shows the associations of species being accepted as weeds essentially in permanent artificial aquatic environments. Oxycarium and Echinochloa seem to constitute the higher risks because of their capability to form floating mats and their distribution in all the guyanese aquatic environments, particularly in artificial environments. Their development could be favoured by the very jagged shoreline allowing their accumulation and by anchoring on the branches of summerged trees. The growth of Salvinia which should form a floating 'pre-mat' could further the installation of this macrophytes.

In contrast, the risk of proliferation of Eichhornia crassipes seems less important owing to its absence in the river Sinnamary and to its limited localization in the regions of Mana and 
Kaw. But their spread is possible in the lake zone and their development could be favoured by mineral elements and nutrients being released in hypolimnion from soil and organic matter decomposition. However the expected short renewal time is a favourable characteristic of the functioning of the reservoir which could reduce the concentrations of these chemical parameters by leaching.

In expectation of the invasion by weeds, it is necessary to prepare the means of their control. It is known from experience that combined treatments (chemical and biological) have the best results. Nevertheless, the controled fluctuations of the water level allow to destruct the mats of floating plants, if the management of the power plant production permits. In the assumption of a moderate invasion of the lake, this method presents the least side effects on the environment. In any case, it is also known from experience that earliness and quickness of intervention always reduce the risks of weed proliferation.

\section{REFERENCES}

Addor E.E., 1977. Experiments on biocontrol of water hyacinth with multiple agents. Bot. Soc. Am. Publ., Misc. Ser., 154, 24.

Anonyme, 1983. Dam the Amazon full stream ahead. Natural history, July 1983, 60-67.

Bennett F.D., 1984. Biological control of aquatic weeds. in: $G$. Thyagarajan
(Ed), Proc. Int. Conf. Water Hyacinth, UNEP, Nairobi, 14-40.

Bennett F.D., Zwölfer H., 1968. Exploration for natural enemies of water hyacinth in northern S. America and Trinidad. Hyacinth Control J., 7, 44-52.

Berg A., 1961. Tôle écologique des eaux de la cuvette congolaise sur la croissance de la jacinthe d'eau (Eichhornia crassipes (Mart.) Solms). A.R.S.O.M. Mémoires, Brussel, 12, 3, 1-120.

Carr A.F., 1952. Handbook of turtles. Comstock Publ. Assoc., Ithaca, N.Y.

Chadwick M.J., Obeid M., 1966. A comparative study of the growth of Eichhornia crassipes Solms and Pistia stratiotes L. in water culture. J. Ecol., 54, 563-575.

Conway K.E., Cullen R.E., Freeman T.E., Cornell J.A., 1979. Field evaluation of Cercospora rodmanii as a biological control of water hyacinth. Misc. Paper A-79-6. U.S. Army Engrs Watenways Expt. Sta., Vicksburg, $46 \mathrm{p}$.

Cook C.D.K., 1974. Water plants of the world. Dr. W. Junk (Publ.), The Hague, $561 \mathrm{p}$.

Desougi L.A., 1984. Mineral nutrient demands of the water hyacinth (Eichhornia crassipes (Mart.) Solms) in the White Nile. Hydrobiologia, 110, 99-108.

Forna I.W., Bourne A.S., 1984. Studies in South America of arthropods on the Salvinia auriculata complex of floating ferns and their effects on S. molesta. Bull. Entomol. Res., 75, 609-621.

Fournet J., 1978. Flore illustrée des phanérogammes de Guadeloupe et de Martinique. I.N.R.A., Paris, 1654 p.

Gopal B., 1987. Water hyacinth. Aquatic Plant Studies 1. Elsevier Sci. (Publ.), $471 \mathrm{p}$.

Granville J.J. de, 1976. Un transect à travers la savane Sarcelle (Mana, Guyane Française). Cah. O.R.S.T.O.M., Ser. Biol., 11, 1, 3-21.

Jonker Verhoef, A.M.E., 1968. Pontederiaceae. In: Pulle A.A. \& Lanjouw J. (Eds), Flora of Surinam, Vol. 1 (Pt. 2), E.Y. Brill (Publ.), Leiden, 81-90. 
Junk W.J., 1982. Zur Entwicklung aquatischer Macrophyten in Curua-Una, dem Ersten Stausee in Zentralamazonien. Arch. Hydrobiol., 95, 169-180.

Lasher C.W., 1977. Tilapia mossambica as a fish for aquatic weed control. Progressive Fish Culturist, 29, 48-50.

Lecoute P., 1947. Arrores e plantas uteis. Amazonia Brasileira 3. Brasiliana, Sao Paulo, ser. 5, 251, 506 p.

Leidermann L., Figueiredo P., 1967. Exterminacao do "Aguape de Cordao" Eichhornia azurea Kunth no Ribeira pela aplicacao de herbicidas. Biologico, Brazil, 33 (6), 121-125.

Lemee A., 1952-1956. Flore de la Guyane Française. 4 vol.

Lindeman J.C., 1953. The vegetation of the coastal region of Suriname. Kemink en zoon N.V., Utrecht.

Oki Y., Ito M., Ueki K., 1978. Studies on the growth and reproduction of water hyacinth, Eichhornia crassipes (Mart.) Solms. I. Effect of nutrients on the growth and reproduction. Weed Res., Tokyo, 23, 115-120.

Paiva M.P., 1977. The environmental impact of man-made lakes in amazonian region of Brazil. Proc. Symp. Manmade Lakes and Human health. Panama, Pandayrs (Ed), 52-73.

Philipp O., Koch W., Köser H., 1983. Utilization and control of water Hyacinth in Sudan. GTZ Schriftenreihe 122. Ger- man Agency for Technical Cooperation, eschborn, 224 p.

Pieterse A.H., Van Rijn P.J., 1974. A preliminary study on the response of Eichhornia crassipes, Salvinia auriculata and Pistia stratiotes to glyphonate. Meded. Fakulteit Landbouwetenschappen Rijksuniv. Gent (Belgium), 39, 423-427.

Sioli H., 1975. Tropical rivers as expressions of their terrestrial environments. In : Tropical ecological systems. Trends in terrestrial and aquatic research, Springer Verlag Publ., 275-288.

Sutton D.L., 1977. Grass carp (Ctenopharyngodon idella Val.) in North America. Aquat. Bot., 3, 157-166.

Theriot E.A. 1981. Large scale field application of Cercospora rodmanii. Proc. 15th Ann. Meeting Aquatic Pl. Control. U.S. Army Engrs Waterways Expt. Sta., Vicksburg, Misc. Paper A 81, 3, 491-492.

Tonopi G.T., Varghese G., 1983. Freshwater turttles as strong predators of water hyacinth. Curr. Sci., 52, 1201-1202.

Widyanto L.S., 1979. The effect of herbicides on water hyacinth. Proc. 7th Asian Pacific Weed Sci. Soc. Cont. Sydney, Suppl. Vol., 51-53.

Wright A.D., Center T.D., 1984. Biological control: its place in the management of water hyacinth. In: G. Thyagarajan (Ed.), Proc. Int. Conf. Water Hyacinth, UNEP, Nairobi, 793-802. 


\section{ANNEXE 1.}

List of the macrophytes observed in the aquatic environments of French Guyana

\begin{tabular}{|c|c|c|c|}
\hline No & Taxonomic units & Family & $\begin{array}{c}\text { Blological } \\
\text { type }\end{array}$ \\
\hline $\begin{array}{r}1 \\
2 \\
3 \\
4 \\
5 \\
6 \\
7 \\
8 \\
9 \\
10 \\
11 \\
12 \\
13 \\
14 \\
15 \\
16 \\
17 \\
18 \\
19 \\
20 \\
21 \\
22 \\
23 \\
24 \\
25 \\
26 \\
27 \\
28 \\
29 \\
30 \\
31 \\
32 \\
33 \\
34 \\
35 \\
36 \\
37 \\
38 \\
39 \\
40 \\
41 \\
42 \\
43\end{array}$ & $\begin{array}{l}\text { Cyperus articulatus } \\
\text { Cyperus giganteus } \\
\text { Cyperus haspan } \\
\text { Eleocharis flaccida } \\
\text { Eleocharis interstincta } \\
\text { Eleocharis mutata } \\
\text { Eleocharis sagotii } \\
\text { Eleocharis retoflexa } \\
\text { Eleocharis geniculata } \\
\text { Fimbristylis sp } \\
\text { Fuirena umbellata } \\
\text { Oxycarium cubense } \\
\text { Cyperus polystachios } \\
\text { Rhynchospora amazonica } \\
\text { Rhynchospora corymbosa } \\
\text { Rhynchospora cyperoides } \\
\text { Rhynchospora gigantea } \\
\text { Rhynchospora graminea } \\
\text { Rhynchospora holoshoenoides } \\
\text { Scirpus maritimus } \\
\text { Scirpus sp. } \\
\text { Scleria microcarpa } \\
\text { Torulinum ferax } \\
\text { Rhynchospora sp. } \\
\text { Typha angustifolia } \\
\text { Andropogon sp. } \\
\text { Bracharia sp. } \\
\text { Bracharia purpurescens } \\
\text { Echinochloa polystachia } \\
\text { Echinochloa sp. } \\
\text { Hymenachne amplexicaulis } \\
\text { Leersia hexandra } \\
\text { Oryza sp. } \\
\text { Panicum cyanescens } \\
\text { Panicum maximum } \\
\text { Panicum mertensii } \\
\text { Panicum sp1 } \\
\text { Panicum sp2 } \\
\text { Panicum parviflorum } \\
\text { Paspalum vaginatum } \\
\text { Paspalum virgatum } \\
\text { Paspalum sp. } \\
\text { Sporobolus virginicus } \\
\text { and }\end{array}$ & $\begin{array}{l}\text { Cyperaceae } \\
\text { Cyperaceae } \\
\text { Cyperaceae } \\
\text { Cyperaceae } \\
\text { Cyperaceae } \\
\text { Cyperaceae } \\
\text { Cyperaceae } \\
\text { Cyperaceae } \\
\text { Cyperaceae } \\
\text { Cyperaceae } \\
\text { Cyperaceae } \\
\text { Cyperaceae } \\
\text { Cyperaceae } \\
\text { Cyperaceae } \\
\text { Cyperaceae } \\
\text { Cyperaceae } \\
\text { Cyperaceae } \\
\text { Cyperaceae } \\
\text { Cyperaceae } \\
\text { Cyperaceae } \\
\text { Cyperaceae } \\
\text { Cyperaceae } \\
\text { Cyperaceae } \\
\text { Cyperaceae } \\
\text { Typhaceae } \\
\text { Poaceae } \\
\text { Poaceae } \\
\text { Poaceae } \\
\text { Poaceae } \\
\text { Poaceae } \\
\text { Poaceae } \\
\text { Poaceae } \\
\text { Poaceae } \\
\text { Poaceae } \\
\text { Poaceae } \\
\text { Poaceae } \\
\text { Poaceae } \\
\text { Poaceae } \\
\text { Poaceae } \\
\text { Poaceae } \\
\text { Poaceae } \\
\text { Poaceae } \\
\text { Poaceae }\end{array}$ & $\begin{array}{l}\text { he } \\
\text { he } \\
\text { he } \\
\text { he } \\
\text { he } \\
\text { he } \\
\text { he } \\
\text { he } \\
\text { he } \\
\text { he } \\
\text { he } \\
\text { he } \\
\text { he } \\
\text { he } \\
\text { he } \\
\text { he } \\
\text { he } \\
\text { he } \\
\text { he } \\
\text { he } \\
\text { he } \\
\text { he } \\
\text { he } \\
\text { he } \\
\text { he } \\
- \\
\text { he } \\
\text { he } \\
\text { he } \\
\text { he } \\
\text { he } \\
\text { he } \\
\text { he } \\
\text { he } \\
\text { he } \\
\text { he } \\
\text { he } \\
\text { he } \\
\text { he } \\
\text { he } \\
\text { he } \\
\text { he } \\
\text { he }\end{array}$ \\
\hline
\end{tabular}




\begin{tabular}{|c|c|c|c|}
\hline No & Taxonomic units & Family & $\begin{array}{c}\text { Blological } \\
\text { type }\end{array}$ \\
\hline $\begin{array}{r}46 \\
47 \\
49 \\
50 \\
51 \\
53 \\
54 \\
55 \\
56 \\
57 \\
58 \\
59 \\
60 \\
61 \\
62 \\
63 \\
64 \\
65 \\
66 \\
67 \\
68 \\
69 \\
70 \\
71 \\
72 \\
73 \\
74 \\
76 \\
77 \\
78 \\
79 \\
80 \\
81 \\
84 \\
87 \\
88 \\
89 \\
90 \\
91 \\
92 \\
93 \\
94 \\
95 \\
96 \\
97 \\
98 \\
99 \\
100 \\
101 \\
102 \\
103 \\
104 \\
105 \\
106\end{array}$ & $\begin{array}{l}\text { Acnida sp. } \\
\text { Aeschynomene sensitiva } \\
\text { Caperonia sp. } \\
\text { Crinum erubescens } \\
\text { Desmodium barbatum } \\
\text { Heliconia psittacorum } \\
\text { Hibiscus sp. } \\
\text { Hydrocotyle umbellata } \\
\text { Hydrolea spinosa } \\
\text { lpomea aquatica } \\
\text { Ludwigia nervosa } \\
\text { Ludwigia leptocarpa } \\
\text { Ludwigia rigida } \\
\text { Ludwigia sp. } \\
\text { Lindernia sp. } \\
\text { Mimosa sp. } \\
\text { Montrichardia arborescens } \\
\text { Neptunia sp. } \\
\text { Polygonum acuminatum } \\
\text { Rhyncanthera grandiflora } \\
\text { Sagittaria lanciflora } \\
\text { Sesbania exasperata } \\
\text { Thalia geniculata } \\
\text { Thurnia sp. } \\
\text { Vallisneria sp. } \\
\text { Xyris jupicai } \\
\text { Xyris sp. } \\
\text { Azolla sp. } \\
\text { Acrostichum aureum } \\
\text { Blechnum serrulatum } \\
\text { Ceraptoteris sp. } \\
\text { Salvinia auriculata } \\
\text { Thelypteris sp. } \\
\text { Nitellopsis sp. } \\
\text { Cabomba aquatica } \\
\text { Eichhornia diversifolia } \\
\text { Eichhornia azurea } \\
\text { Eichhornia crassipes } \\
\text { Eriocaulon sp. } \\
\text { Limnobium stoloniferum } \\
\text { Mayaca longipes } \\
\text { Mayaca fluviatilis } \\
\text { Myriophyllum spicatum } \\
\text { Nymphea ampla } \\
\text { Nymphea amazonum } \\
\text { Nymphea rudgeana } \\
\text { Nymphoides indica } \\
\text { Pistia stratiotes } \\
\text { Tonina fluviatilis } \\
\text { Utricularia sp1 } \\
\text { Utricularia sp2 } \\
\text { Utricularia sp3 } \\
\text { Utricularia sp4 } \\
\text { Wolffiella sp. }\end{array}$ & $\begin{array}{l}\text { Amaranthaceae } \\
\text { Papilionaceae } \\
\text { Euphorbiaceae } \\
\text { Amaryllidaceae } \\
\text { Papilionaceae } \\
\text { Strelitziaceae } \\
\text { Malvaceae } \\
\text { Apiaceae } \\
\text { Hydrophyllaceae } \\
\text { Convolvulaceae } \\
\text { Onagraceae } \\
\text { Onagraceae } \\
\text { Onagraceae } \\
\text { Onagraceae } \\
\text { Scrophulariaceae } \\
\text { Mimosaceae } \\
\text { Araceae } \\
\text { Mimosaceae } \\
\text { Polygonaceae } \\
\text { Melastomaceae } \\
\text { Alismataceae } \\
\text { Papilionaceae } \\
\text { Marantaceae } \\
\text { Thurniaceae } \\
\text { Hydrocharitaceae } \\
\text { Xyridaceae } \\
\text { Xyridaceae } \\
\text { Azollaceae } \\
\text { Adiantaceae } \\
\text { Blechnaceae } \\
\text { Parkeriaceae } \\
\text { Salviniaceae } \\
\text { Parkeriaceae } \\
\text { Characeae } \\
\text { Cabombaceae } \\
\text { Pontederiaceae } \\
\text { Pontederiaceae } \\
\text { Pontederiaceae } \\
\text { Eriocaulaceae } \\
\text { Hydrocharitaceae } \\
\text { Mayacaceae } \\
\text { Mayacaceae } \\
\text { Haloragaceae } \\
\text { Nympheaceae } \\
\text { Nympheaceae } \\
\text { Nympheaceae } \\
\text { Menyanthaceae } \\
\text { Araceae } \\
\text { Eriocaulaceae } \\
\text { Lentibulariaceae } \\
\text { Lentibulariaceae } \\
\text { Lentibulariaceae } \\
\text { Lentibulariaceae } \\
\text { Lentibulariaceae }\end{array}$ & $\begin{array}{l}- \\
\text { he } \\
\text { He } \\
- \\
- \\
\text { he } \\
\text { He } \\
\text { he } \\
\text { he } \\
\text { he } \\
\text { he } \\
\text { he } \\
\text { he } \\
\text { he } \\
\text { He } \\
\text { - } \\
\text { he } \\
- \\
\text { hy } \\
\text { he } \\
\text { he } \\
\text { hy } \\
\text { he } \\
\text { he } \\
\text { hy } \\
\text { he } \\
\text { he } \\
\text { he } \\
\text { hy } \\
\text { he } \\
\text { hy } \\
\text { hy } \\
\text { hy } \\
\text { hy } \\
\text { hy } \\
\text { hy } \\
\text { hy } \\
\text { hy } \\
\text { hy } \\
\text { hy } \\
\text { hy } \\
\text { hy } \\
\text { hy } \\
\text { he } \\
\text { hy } \\
\text { hy } \\
\text { hy } \\
\text { hy } \\
\text { hy } \\
\text { hy } \\
\text { hy }\end{array}$ \\
\hline
\end{tabular}

